\title{
Be Motor Impaired and "Psychically Re-inhabit" His Body While Incarcerated: A Case Study of Adult Incarcerated in Cameroon
}

\author{
Emilie Clarisse Tchokote \\ Department of Sciences of Education, Higher Teacher Training College (HTTC), University of Yaounde I, Yaounde I, Cameroon \\ Email address: \\ emilietchoko@yahoo.fr \\ To cite this article: \\ Emilie Clarisse Tchokote. Be Motor Impaired and "Psychically Re-inhabit" His Body While Incarcerated: A Case Study of Adult \\ Incarcerated in Cameroon. Psychology and Behavioral Sciences. Vol. 9, No. 6, 2020, pp. 99-104. doi: 10.11648/j.pbs.20200906.12
}

Received: November 8, 2020; Accepted: November 23, 2020; Published: December 4, 2020

\begin{abstract}
The motor disability leads to a limitation and a restriction of some activities due to an alteration of physical function. Through this study, the author aims to understand the meaning of body confinement experience to the incarcerated adults faced with a motor deficiency. Three adults met at the Mfou principal prison (Cameroon). The semidirective interview and Rorschach's projective test have been used as tools to collect data. The semi-directive interview guide was based on themes link to the history of the incarcerated situation, the experience of body confinement, the nature of body image structuration and the body investment or disinvestment. In the Rorschach test, there is no projection of the body known by the person, and which would be the object of cognitive activity, but the body as it is lived, felt, desired as an object and subject of emotional activity. The thematic content analysis was used for the interview. The qualitative and quantitative analysis were used to analyze Rorschach test. The result of the interview shows that the subject painfully experiences the body confinement, the shame and humiliation feeling makes the body to be perceived as 'body-object'. The psychic fragility is shown and generated a set of symptoms that goes to self fold, body disinvestment, up to suicide attempt. The Rorschach test results show a fragmented and weakened body image, difficult to 're-inhabit' psychically. There is a need for a psychological accompaniment strategies in order to facilitate a 'psychic re-appropriation' of the subject's body.
\end{abstract}

Keywords: Handicap, Motor Deficiency, Bodily Confinement, Prison Environment, Rorschach

\section{Introduction}

Violation of the laws and rules of a society by a person is punishable depending on the nature of the offenses caused. When the sanction is imprisonment, the prison plays the role of a punitive instance, education, reminder of the law and sometimes protection against popular retribution. Cameroon has nearly 123 prisons structured into central prisons (regions), main prisons (departments) and secondary prisons (districts), with a reception capacity lower than the incarcerated population [1]. The subject incarcerated in such a context is deprived of a set of freedom, imposing big physical and mental suffering.

The constraint imposed on the body in a time and a space of incarceration, makes the body the field of a conflict of appropriation upsetting the dialectic between "body-subject" and "body-object" [2]. Physical suffering is perceived through the body confinement, leading to psychological fragility in the subject with or without a disability. The study examines the incarceration situation of adults with motor disabilities who, having committed an offense in the criminal plan, exposed themselves to punitive sanctions with their lot of consequences for their becoming.

It is known that the handicap in a person leads to a limitation of activity, a restriction of participation in life in society due to an alteration of physical, sensory, mental or cognitive functions [3]. Disability results from the deficiency corresponding to the impairment of organs and functions, the incapacity and limitation of the actions of daily life as well as the disadvantage marking the situational level of the handicap [4].

Bréjard and Pedinielli emphasize on the fact that, handicap 
as an ordeal regardless of its origin, calls into question the subject's relationship to his body, to the world and to himself, with different psychological repercussions depending on the age. [3]

Also, it is known that, the mental illness have been found on incarcerated individuals with the observation of severe psychiatric disease and are link to the behavioural management problems [5].

In this case, how does the person who faces a limitation of the gestures and activities of everyday life experience the "bodily confinement" in the prison environment?

The psychopathological theory of the body in relation to the psyche demonstrates the direct effect of the repercussion on the psyche of bodily symptoms and vice versa. In this logic, Joly believes that despite the modifications and changes that a body can undergo, it is still possible to inhabit the body psychically [6-8]. Inhabiting one's body would therefore be "a psychic act based on the sensory which participates in the construction of its identity [...]" This is to say that a damaged body can inhabit like a house and participate in a process of identity construction [9].

Motor deficiency constitutes a deep narcissistic attack in the subject. The effect of the difference induced by body modifications causes a permanent readjustment of thought patterns, experiences, focusing attention on the areas of the body concerned. However, the subject who is already facing these readjustments will have to face the constraints due to the situation of confinement of the body. The prison can impact on people by altering their temporal, spatial and bodily dimensions. Their emotional life can be affected and also their identity.

In this context, how will the subject be able to "re-inhabit his body" in a psychic way?

\section{Methods}

It is an in-depth study of the human being considered in his singularity, his experience, which takes into account the search for meaning [10-12]. The goal is to understand the meaning of the lived experience of bodily confinement in three adult men aged 29, 34 and 38 respectively, in a situation of motor impairment and incarcerated for various crimes at the main prison of Mfou (central region of Cameroon).

The selection of participants is made according to the study's inclusion criteria: being an adult male and without intellectual impairment; have an acquired or congenital motor impairment; have been in prison for at least one year. The free consent forms were signed by the participants allowing the data collection under pseudonyms (Octa, JP, Ondo).

The semi-structured interview guide and the Rorschach projective test served as research tools.

Theoretical considerations in Rorschach and the test administration from the perspective of Rausch and Boizou and Rausch de Traubenberg states that, in this test there is no projection of the known own body and which would be the object of cognitive activity, but rather of the experienced body as the object and subject of affective activity $[13,14]$.

Six semi-structured interviews were carried out (two interviews per participant) with the theme based on the history of imprisonment, the experience of deprivation and bodily confinement, the structuring of body image and investment or bodily disinvestment.

The Rausch de Traubenberg's techniques of thematic content analysis and quantitative and qualitative Rorschach analysis were used [14].

\section{Results}

\subsection{Idiographic Presentation of Participants}

1. Octa

Octa is 38 years old, single and unemployed. He holds a CAP (Certificate of Professional Aptitudes). He is the Elder of a monogamous family of two children, he was the victim of a traffic accident when he was 28 years old, causing partial impairment of motor skills in his lower right limb. He uses a crutch to move around and has been incarcerated for theft and breach of trust for two years.

2. JP

JP is 29 years old, single and unemployed. He continued his primary education up to class six. He is the fourth child of five siblings, he was the victim of a traffic accident when he was 21 years old. He has been incarcerated at Mfou main prison for theft for a year and four months.

3. Ondo

Ondo is 34 years old, Single and father of two children. He is unemployed and has not completed his studies from secondary education to the Section "Rural Artisanal" (SAR) in building construction. He is the fourth in a family of five, children. He has a motor deficiency and uses two crutches. He has been imprisoned for a year and six months for fraud following a double sales of land.

\subsection{Analysis of Interview Data}

\subsubsection{Lived of Deprivation and Physical Confinement}

The participants justified the deprivation of their liberty by their anti-social behaviour. They experience painfully this confinement which confers on the body, the status of "bodyobject" experienced in shame. The humiliation is experienced painfully through the arrest and incarceration conditions. JP specifies that "it is very bad, when one (police officer) comes to pick you up like that in the neighbourhood, in front of your neighbours, your family members, you lose the strength to speak!"

Beyond bodily expression, verbal expression also struggles to be externalize, thus marking the discomfort felt. Ondo said "in front of my children and their mother, they came to humiliate me in the neighbourhood" (Silence) I'm not denying what I did, but, not in front of my children! ". The subject experienced shame accentuated by the gaze of the other (children, neighbours, partner), questioning his parental 
authority.

Therefore, the subject perceives his body through the gaze of the other as a "body-object" devoid of substance and which loses all possibility of action on the world.

The participant Octa specifies that "to think that I am here (prison) really, I no longer have the taste for life, and I'm ashamed! One wonders if despite my disability, I do not feel sorry for my own body! ". This verbalization shows the psychological discomfort experienced by the subject as a result of his imprisonment. Bodily confinement tests the subject's psychological resources and makes him vulnerable; hence a deterioration of the bond with others and a deep narcissistic attack of the body.

The carceral influence leaves traces on the body through a set of rite of passage which is operated as specified by JP "As soon as we get here, we are searched, we take everything we have in our pockets, jewellery, everything!"

The modes of body treatment refers to physical violence (manipulation of the body) and symbolic violence through the repercussions of this act in the psychic economy "body devoid of any substance, objectified, deprived of privacy and autonomy".

However, the subject is already experiencing the limitation of his motor functions with the social disadvantage, exacerbating the psychological suffering; "Living here is very difficult, we don't eat well, if the family doesn't visit us, we may die! We have to sell everything in prison to resist! For us who are disabled, it is very complicated!" (Ondo).

\subsubsection{Structuring OF Body Image and Bodily Disinvestment}

The effects of loss of motor functions reanimate the feeling of altered self-image, accentuated by the gaze of the other. With incarceration, this feeling is exacerbated in a perception of the body in perpetual psychic fragility.

This is reinforced by the limits imposed by the new framework (prison), generating psychological disorders in the subject (withdrawal into oneself, isolation, depression, suicide attempts) (Octa and Ondo). The body image is perceived by the participants as "fragmented", with damage to the psychic envelope.

The enveloping structures playing the role of psychic containers are found to be altered and lack care (bodily care, psychic care). JP specifies "[...] I am in great pain, my body no longer looks like anything! When I was at home I took care of myself! Now my body has no more sense! ". We also find the disinvestment of the body in Ondo and Octa through the lack of care to be provided. The body is at the center of preoccupations, because starting from the incarcerated "body object" enclosed in a space, to become an "objectified" body, deprived of its attributes and its primary identity.

In such a situation, there is a passage from "body-subject" to "body-object", which causes regret and disinvestment. Octa says "I had a lot of ambition! But with all my problems, I find myself in this situation! I think a lot and I often forget myself! I'm not taking care of myself! "

Table 1. Illustration of the results of the interview.

\begin{tabular}{|c|c|c|c|}
\hline Participants & Octa & $\mathbf{J P}$ & Ondo \\
\hline Idiographic data & $\begin{array}{l}\text {-35 years old; } \\
\text {-Elder of two siblings; } \\
\text { - Single; } \\
\text {-Victim of accident at } 28 \text { years old; } \\
\text {-Partial impairment of motor skills in his lower } \\
\text { right limb; } \\
\text { - Incarcerated for theft and breach of trust for } \\
\text { two years. }\end{array}$ & $\begin{array}{l}\text {-29 years old; } \\
\text { - Fourth child of five siblings; } \\
\text {-Single; } \\
\text {-Victim of a traffic accident at } 21 \text { years } \\
\text { old; } \\
\text {-Incarcerated for theft for a year and } \\
\text { four months. }\end{array}$ & $\begin{array}{l}\text {-34 years old; } \\
\text { - Fourth child of five siblings; - } \\
\text { Single, father of two children; } \\
\text { - Motor deficiency; } \\
\text {-Uses two crutches to move; } \\
\text { - Incarcerated for fraud (double sales } \\
\text { of land). }\end{array}$ \\
\hline $\begin{array}{l}\text { Lived of } \\
\text { Deprivation and } \\
\text { Physical } \\
\text { Confinement }\end{array}$ & $\begin{array}{l}\text { - Experience painfully the confinement } \\
\text {-"Body-object" experienced in shame, devoid } \\
\text { of substance and which loses all possibility of } \\
\text { action on the world; } \\
\text {-Feeling the humiliation and psychological } \\
\text { discomfort; } \\
\text { - Narcissistic attack of the body } \\
\text {-Body objectified, deprived of privacy and } \\
\text { autonomy; } \\
\text { "[...] I no longer have the taste for life! [...]" }\end{array}$ & $\begin{array}{l}\text { - Experience painfully the confinement } \\
\text {-"Body-object" experienced in shame; } \\
\text {-Feel of discomfort; } \\
\text { - Narcissistic attack of the body; } \\
\text {-Body objectified, deprived of privacy } \\
\text { and autonomy; } \\
\text { "[...] you lose the strength to speak!" }\end{array}$ & $\begin{array}{l}\text { - Experience painfully the } \\
\text { confinement } \\
\text {-"body-object" experienced in shame, } \\
\text { accentuated by the gaze of (children, } \\
\text { neighbours, partner); } \\
\text {-Questioning his parental authority; } \\
\text { - Narcissistic attack of the body. } \\
\text { "in front of my children and their } \\
\text { mother, they came to humiliate me in } \\
\text { the neighbourhood" }\end{array}$ \\
\hline $\begin{array}{l}\text { Structuring OF } \\
\text { Body Image and } \\
\text { Bodily } \\
\text { Disinvestment }\end{array}$ & $\begin{array}{l}\text { - Altered self-image; } \\
\text { - Perception of the body in perpetual psychic } \\
\text { fragility; } \\
\text { - Psychological (withdrawal into oneself, } \\
\text { isolation, depression, suicide attempts); } \\
\text {-Body image "fragmented", with damage to the } \\
\text { psychic envelope. } \\
\text { - Disinvestment of the body; } \\
\text { - Passage from "body-subject" to "body- } \\
\text { object". } \\
\text { "[...] I'm not taking care of myself! " }\end{array}$ & $\begin{array}{l}\text { - Altered self-image; } \\
\text { - Perception of the body in perpetual } \\
\text { psychic fragility; } \\
\text {-Body image "fragmented", with } \\
\text { damage to the psychic envelope; } \\
\text { - Passage from "body-subject" to "body- } \\
\text { object". } \\
\text { "[...] I am in great pain, my body no } \\
\text { longer looks like anything![...] my body } \\
\text { has no more sense!" }\end{array}$ & $\begin{array}{l}\text { - Altered self-image; } \\
\text { - Perception of the body in perpetual } \\
\text { psychic fragility; } \\
\text { - Generating psychological disorders } \\
\text { in the subject (withdrawal into } \\
\text { oneself, isolation, depression, suicide } \\
\text { attempts; } \\
\text { - Disinvestment of the body; } \\
\text { - Passage from "body-subject" to } \\
\text { "body-object". }\end{array}$ \\
\hline
\end{tabular}




\subsection{Quantitative and Qualitative Analysis of the Rorschach Test}

\subsubsection{Quantitative Analysis}

The entry into the test demonstrates a deep discomfort in the desire for verbal expression among participants. Because the initial latency times vary from 5 seconds (Octa), to 2 seconds (Ondo). Only JP shows an initial latency of 22 seconds. We notice that the latency time is high in Octa at the card IX (11 seconds) and card X (20 seconds) showing the subject's inability to neutralize his reactions due to associative stupor, since these images refer to the deterioration of the human body (card IX) and the bursting or fragmentation of the body parts (card X).

In the case of JP, the latency time is high at the card VIII (48 seconds) and at VI (40 seconds), while, the card VIII calls for more exchange and social communication with a strong somatic preoccupation, hence the explicit avoidance of the subject.

The apprehension modes are perceptible in the psychogram of all the subjects $(G, D)$ with a predominance of responses in great detail. The Global response $(\mathrm{G})$ are generally associated with a poverty of formal response. The formal aspect $\mathrm{F} \%$ being lower than normal, demonstrates the dominance of the affective aspects (Octa, F\% $=30 \%$; JP, $\mathrm{F} \%=10 \%$; Ondo, $\mathrm{F} \%=33 \%$ ).

The projective pole (kinesthesic) is represented (Ondo, $\mathrm{K}=5$; Octa, $\mathrm{K}=7$ ), which reflects a search for identification, a projection of fantasies linked to the disintegration of the body; the Intimate Resonance Type (IRT) is mixed Introversive in all participants (JP, $5 \mathrm{~K} / 0 \sum \mathrm{C}$; Octa, $7 \mathrm{~K} / 0 \sum \mathrm{C}$; Ondo, $\left.5 \mathrm{~K} / 0,5 \sum \mathrm{C}\right)$, which reflects a concern for the subject's personality, aware of his difficulties and who lets himself be absorbed by his imaginary contemplations with a domination of his imaginary interior world over external reality.

The Content are dominated by the responses of animal type (Ondo, $A=15$; Octa, $A=9$ ), showing the subject defensive attitude, which tends to substitute humans for animals despite the recognition of preoccupation related to the body through the raised of human responses $(\mathrm{H})$.

A low percentage of animal content $(A=3, A \%=30 \%)$ was observe only in the psychogram of JP, that shows a defensive attitude to camouflage its deep interests.

Table 2. Illustration of quantitative results of the Rorschach.

\begin{tabular}{|c|c|c|c|}
\hline Participants & Octa & $\mathbf{J P}$ & Ondo \\
\hline $\begin{array}{l}\text { Psychogram } \\
\text { of subjects }\end{array}$ & $\begin{array}{l}\text {-Deep discomfort in the desire for verbal expression } \\
\text { (initial latency, } 5 \text { "); } \\
\text {-High latency time at card IX ( } 11 \text { ") (images refer to } \\
\text { the deterioration of the human body) and card X ( } 20 \text { ") } \\
\text { (fragmentation of the body parts); } \\
\text {-Apprehension modes (G, D) associate with a poverty } \\
\text { of formal response ( } \mathrm{F} \%=30 \%) \text {; } \\
\text { - Kinesthesic pole (K=7); } \\
\left.\text { - Intimate Resonance Type ( } 7 \mathrm{~K} / 0 \sum \mathrm{C}\right) \text {; } \\
\text { - Domination of an imaginary interior world over } \\
\text { external reality; } \\
\text { - Responses of animal type }(\mathrm{A}=9)(\text { defensive attitude, } \\
\text { tends to substitute humans for animals). }\end{array}$ & $\begin{array}{l}\text {-Initial latency ( } 22 ") \\
\text {-Apprehension modes }(\mathrm{G}, \mathrm{D}) \\
\text { associate with a poverty of formal } \\
\text { response }(\mathrm{F} \%=10 \%) \text {; } \\
\text { - Representation of projective pole / } \\
\text { kinesthesic pole }(\mathrm{K}=5) \text {; } \\
\text { - Intimate Resonance Type } \\
\left(5 \mathrm{~K} / 0 \sum \mathrm{C}\right) \text {; } \\
\text {-Domination of an imaginary } \\
\text { interior world over external reality; } \\
\text { - Responses of animal type }(\mathrm{A}=3) \\
\text { (defensive attitude to camouflage its } \\
\text { deep interests). }\end{array}$ & $\begin{array}{l}\text {-Deep discomfort in the desire for verbal } \\
\text { expression (initial latency,2") } \\
\text {-Apprehension modes }(\mathrm{G}, \mathrm{D}) \text { associate } \\
\text { with a poverty of formal response ( } \mathrm{F} \% \\
=33 \%) \text {; } \\
\text {-Representation of projective pole } \\
\text { /kinesthesic pole }(\mathrm{K}=5) \text {; } \\
\text { - Intimate Resonance Type }(5 \mathrm{~K} / 0,5 \mathrm{C} \text { ) } \\
\text {-Domination of an imaginary interior } \\
\text { world over external reality } \\
\text { - Responses of animal type }(\mathrm{A}=15) \\
\text { (defensive attitude, tends to substitute } \\
\text { humans for animals). }\end{array}$ \\
\hline
\end{tabular}

\subsubsection{Qualitative Analysis}

\section{Octa}

From the entrance, the representation of a global form betrays the bodily fragmentation experienced through the anatomical response (anat) coupled with a human kinaesthesia $(\mathrm{K}, \mathrm{H})(\mathrm{G}, \mathrm{K} \mathrm{H}$ anat), in the upright position of the card $\mathrm{I}(\wedge)$ " a assembly of bats (silence), two devils who pull a man's heart! (Laugh)". The mixture of colors in card II (black and red) forces the subject to give a human content response in a sort of festive celebration, of joy "it's a festive aspect, two men who look like father Christmas! Who are getting ready for a party"

The feeling of joy will quickly turn into aggressive content "it's like they are doing arm twisting!" The ambivalence of the emotional tonality oscillates between pleasure and the aggressive drive (party / arm twisting).

The card III is dominated by a human-shaped kinaesthesia with blood and object contents (D, K, H, obj, Sg) "two women who prepare in a pot!".

The imaginative abilities are dominated by the representation of an unhealthy world "these are magical incantations! It's like pouring blood into that pot with the intention of casting a spell on someone! ". Upon investigation, the subject shows an experience of fragmentation of the body parts, "like freshly broken legs of meat!".

Cards IV and V plunge the subject into discomfort when he discusses the elements (devils, monsters, dragon). "It is the physiognomy of a monster" (IV); "The same monster, a representation of the devil with his wings!" (V).

Card VI is marked by human kinaesthesia in bad form with contents (anat and geo) "a man who sits in front of a hill or a mountain! The face, the mustaches with outstretched hands!" This card recalls the symbolism of the body perceived in a frightening and strange form. Card VII and VIII are dominated by poorly geographic and botanical content ( $\mathrm{F}$-) with animal kinaesthesia (kan). These contents reveal somatic preoccupation related to the fragmentation of body parts "below, it looks like a heart. It's the impression of something that has been split open!" (VIII). 
The card IX is marked by resistance to the symbolic call with raw sexual responses in other to mark the body deterioration "a woman's buttocks, a vagina!" It's like this woman is having a bloody discharge! ". The "blood" response coupled with the anatomic content (vagina) demonstrates a solicitation to the regressive position experienced negatively and which refers to a pregenital maternal symbolism.

On a card $\mathrm{X}$, the content is dominated by an animal representation "a jar with insects of all kinds, spiders, owls, birds, which climb! Tailed animals taking their direction, the back looks like a cave". Upon investigation, the subject specifies his positive (II and III) and negative (V and I) choices. The symbolism of card II sends the subject back to joy, despite the aggressive component "arm twisting". The fear and the astonishment felt on the $\mathrm{V}$ card justifies his negative choice "angel of the devil".

\section{JP}

In card I, the overall perceived form is animal kinaesthesia and animal content (G, Kan, A), "some birds that are flying", Cards II and III present (D, K H). The D allows the subject to regain emotional stability through a feeling of pleasure "two bodies in contact!"(II); "Two women doing the same job!" (III).

On card IV, the content (object) perceived under a kinaesthesia shows an enhancement of the phallic symbol in the middle D of the card "a volcanic eruption, a source that springs up and pours out on either side!" Card V shows a (D) and (Kan), "^ (upright position) here it looks like two birds are in contact!"

Poor verbalization reflects the massive struggle against a disorganization of the self or an inability to address the obvious reality. The cards VI and VII are marked by a dominance of objects of poor form "a totemic status of a certain region which is fixed on a plinth" (VI). "^ (upright position), like a trait, it looks like clouds (laughs), that is linked here from below!" (Dd lower median)" (VII).

Card VIII imposes a strong painful emotion on the subject with a long latency time (48 seconds), and a Kan in an apprehension of (D); "An organism or two identical animals which are attached to this organism on both sides and in contact with the sky! Is it human or animal?"

This imprecision suggests an invasion of strong emotional charge due to the handling of colors. Card IX reveals the somatic preoccupations masked in (VIII) with a dominance on the quest for identification and bodily unity; "Almost similar! Two bodies in green on either side which are on the same base and communication points at the top!"

The "organism" response perceived in (VIII) finds an answer in the human "bodies" content that the subject struggles to exteriorize and which is traced back to card X "here it is several organisms which are connected to each other, with their own personality!". We note a desire of the subject to verbalize a certain positive emotional charge, in other to search for body unity, hence the positive choice of this card.

3. Ondo
On card I, the dominant apprehension mode is $(\mathrm{G})$ coupled with animal content accompanied by banality (ban); " $A$ scorpion! A flag, the bat!". The absence of kinaesthetic perception seems to reflect the lack of mobility of the subject, who finds himself imprisoned without the possibility of movement. On card II, the subject mainly perceives the (D) with human contents sometimes in movement $(\mathrm{K})$ sometimes in a vague way; "As if two people greeting each other stretching out two hands sideways, two people crossing their arms, like two gorillas!"

The feeling of bodily disorganization is masked and the subject highlights painful and aggressive experiences "in front of me, I see like two ghosts!" Like these two people were saying no to witchcraft! I can take that like monstrous people!"

The painful emotion felt at the end of the card II seems to continue at III and IV when the subject evokes "something monstrous, like a raging gorilla, a ghost, a threatening wizard!" The devil, awful stuff! "(IV).

This same emotion is felt on the V and VI cards "this again? It's true that he (monster) has two legs, horns on his head, wings like a bat! You only have monstrous stuff there! "(V). The defence mechanism is put in place to protect against the devastating effect of the painful feeling in a kind of fragmentation of the parts. "Are these monsters? There I see a column, a head, they are semblance of wings! " (VI).

The emotional stability is seen in card VII through a small detail of animal content in a kinaesthetic form accompanied by the elements, "an insect in the middle that turns the heat!" (Dd lower median) ". Cards VIII and IX suggest an animal kinaesthetic (Kan) with significant somatic concerns marked by "injection" aggressiveness. "Two chameleons on the sides (red detail), there are two people! Chameleons inject color into the people below! " (VIII). "It's like an injection from a crab or a scorpion!" (IX). The dominant (Kan) demonstrates the painful emotional burden, felt because of the fragmentation of body parts substituted for the animal "for sure it is the same scorpion injecting its venom somewhere in the human body." (X).

\section{Discussion}

The participants painfully experience the bodily confinement, marked by the deprivation of being able to invest the body in an enclosed space (the prison), with feelings of shame and bodily objectification. This would have an impact on the structuring of the body image through a suffering body that is difficult to "inhabit" psychically.

The lack of bodily investment among the participants would actually be the consequence of feeling experience of an "Un-Heimlich" in the Freudian sense of disturbing strangeness.

The results of the Rorschach test confirm this point of view, notably with the perception of the body as fragmented and weakened.

However, knowing with Brun that a damaged body can always "live like a house and participate in a process of 
identity construction", re-habit your body psychically in a context of disability and imprisonment seems to constitute a painful task [9]. This has an impact on the subject's psyche and upsets his reference points on the relational, behavioural and lifestyle levels. The discovery of a new environment with its rules and codes (prison) and the loss of autonomy accentuate the reduction in motor function already imposed by the impairment [15].

Also, some psychiatric disorders are linked to stressful situations and prison shock and can arise from a difficult family and social context [16] For the future research, we suggest to investigate on the impact of peers in the wellbeing of prisoner in general and those facing a handicap in particular.

\section{Conclusion}

The aims of the study is to understand the meaning of body confinement experience to the incarcerated adults faced with a motor deficiency. The results show that the limitation and a restriction of some activities due to an alteration of physical function can affect psychologically the subjects faced with motor disability. Also, the subject painfully experiences the body confinement, considered as 'bodyobject' with feeling the shame and humiliation. The psychic fragility has been observed on the participant. This situation generated a set of psychopathological symptoms. As the qualitative and quantitative results tests of Rorschach show, one observed a fragmented and weakened body image. This body image is difficult to 're-inhabit' psychically. There is a need for a psychological accompaniment strategies in order to facilitate a 'psychic re-appropriation' of the subject's body.

Englebert precise that the fact to imprison the body can altered the relationship of a person according to a space, time, his imaginary world, the identity and the psychic [17]. It is therefore recommended to provide mobility devices and therapy for prisoners with disabilities. In this case, psychological support will allow the subject to "reappropriate" his own body so as to combine both the inner imagination and the outer reality. Prisoners with motor disabilities are likely to need help, support and accompaniment [18-20].

\section{References}

[1] Ngono Bounoungou, R. Reform of the Cameroonian prison system: between colonial heritage and cultural traditions. [Thèse de Doctorat]. Université de Grenoble; 2012.

[2] Chamond, J., Moreira, V., Decocq, F et Leroy-Viemon, B. La dénaturation carcérale. Pour une psychologie et une phénoménologie du corps en prison. L'Information psychiatrique 2014; 90: 673-682.
[3] Bréjard, V. et Pedinielli, J-L. Approche psychodynamique du handicap. In: Jover M. (ed). Psychologie et handicap. Presses de L'Université de Provence; 2014; 58-72.

[4] WHO. International Classification of Handicaps, Impairments, Disabilities and Disadvantages. Paris: CTNERHI-INSERM; 1988.

[5] Steadman, H. J., Osher, F. C., Robbins, P. C. et Samuels, S. Prevalence of serious mental illness among jail inmates. Psychiatric services. 2009, Vol 6, No, 60, pp. 761-765.

[6] Joly, F. J'ai mal à mon corps d'enfant (les souffrances corporelles précoces et leurs destins dans l'habitation corporelle de l'adulte). Spirale 2008; 5: 183-195.

[7] Joly, F. Le sens des thérapeutiques psychomotrices en psychiatrie de l'enfant. Neuropsychiatrie de l'enfance et de l'adolescence 2007; 55; 2: 73-86.

[8] Joly, F. Notre corps n'est rien sans le corps de l'autre. Thérapie psychomotrice 2003; 134: 40-58.

[9] Brun, D. Inhabit your body. Recherche en psychanalyse 2006; 2, 6: 7-10.

[10] Douville, O. Clinical methods in psychology. Paris: Dunod; 2006.

[11] Fernandez, L., Catteeuw M. Research in clinical psychology. Paris: Nathan; 2001.

[12] Muchielli, A. Dictionnaire des méthodes qualitatives en sciences humaines et sociales. 3è éd. Paris: Armand Colin; 2009.

[13] Rausch de Traubenberg, N. et Boizou, M. Le Rorschach en clinique infantile. Paris: Dunod; 1984.

[14] Rausch de Traubenberg, N. The practice of Rorschach. Paris: PUF; 1997.

[15] Roustant, J-Ph. Psychopathology of the gaze and the act in the clinic of the incarcerated subject.. 2017 [consulté le 04 Février 2020] sur le site https://tel.archives-ouvertes.fr

[16] Tesu-Rollier, D. et Coutanceau, R. Clinique et psychopathologie en milieu carcéral. A propos d'une expérience de pratique à la maison d'arrêt de fleury-Mérogis. Annales Médico-Psychologiques 2007; 165: 8-12.

[17] Englebert, J. Psychopathology of the human in situation. The inmate's body in the prison environment. Paris: Editions Hermann, 2013.

[18] Désesquelles, A. Disability in prison in France. What are the differences with the situation in the general population? Population 2005; 60: 71-98.

[19] Padiolleau, C. Detention and dependency: Care of people with disabilities in prison. 2013 [consulté le 02 février 2020] sur le site https://www.enap.justice.fr

[20] Morgan, J. et Liman A. Prisoners with physical disabilities are forgotten and neglected in America. 2017. [consulté le 04 Novembre 2020] sur le site https://www.aclu.org/blog/prisoners-rights/solitaryconfinement/prisoners-physical-disabilities-are-forgotten-and. 